\title{
Human papillomavirus infection of the uterine cervix of women without cytological signs of neoplasia
}

\author{
PHILIP G TOON， JOHN R ARRAND， LYNNE P WILSON， DAVID S SHARP
}

\begin{abstract}
One hundred and six patients were studied whose cervical smears showed only non-specific inflammatory changes. Screening for genital pathogens yielded only a few positive cases. Histological examination of biopsy specimens taken by colposcopically directed tissue sampling showed cervical intraepithelial neoplasia in 13 of the women $(12 \cdot 3 \%)$. Deoxyribonucleic acid (DNA) hybridisation techniques were used to detect human papillomavirus, which was found in 24 patients ( $22 \cdot 6 \%$ ).

In a second group of 10 s patients with normal cervical cytology tissue biopsy samples were obtained and examined histologically but in no case was cervical intraepithelial neoplasia found. On DNA hybridisation, however, 12 patients $(11 \cdot 5 \%)$ were found to be positive for human papillomavirus. In this group finding human papillomavirus DNA was usually associated with a columnar ectopy.

An association between human papillomavirus type 16 DNA and both cervical intraepithelial neoplasia and cervical cancer is well established. In this study it was type 16 which occurred most frequently in both groups.
\end{abstract}

\section{Introduction}

Consequent on the colposcopic identification of cervical condylomas, Meisels et al in 1977 postulated that wart virus infection of the cervix might be a precursor of cervical neoplasia. ${ }^{\prime}$ This hypothesis has been reinforced both by histological evidence of viral

\footnotetext{
Department of Obstetrics and Gynaecology, North Manchester General Hospital, Manchester M8 6RB

PHILIP G TOON, MRCOG, research fellow

DAVID S SHARP, MRCOG, consultan

Department of Molecular Biology, Paterson Laboratories, Christie Hospital and Holt Radium Institute, Manchester M20 9BX

JOHN R ARRAND, PHD, senior scientist

LYNNE P WILSON, BSC, research technician

Correspondence and requests for reprints to: Dr Arrand.
}

infection associated with cervical intraepithelial neoplasia and cervical cancer $^{2}$ and by DNA-DNA (deoxyribonucleic acid) hybridisation using specific human papillomavirus DNA probes. Indeed, human papillomavirus types 16 and 18 were both originally identified from cervical carcinoma tissue. ${ }^{89}$

This study was initiated because of concern that a small but appreciable number of women, especially in the under 35 year age group, whose previous cervical smears showed only inflammatory changes without the intermediate changes of cervical intraepithelial neoplasia were presenting with invasive cervical carcinoma $(R$ Hunter, personal communication). The study was designed to identify, using bacteriological, virological, and chlamydial culture and colposcopy, histology, and molecular biology, any potential causative agent(s) of these inflammatory cervical smears. For the purpose of the study a non-specific inflammatory cervical smear was defined as one showing polymorphonuclear leucocytes and degeneration (intracytoplasmic vacuoles, perinuclear halo formation, and pyknosis $)^{10}$ in the absence of any histological evidence of specific infective agents.

\section{Patients and methods}

The study was approved by the district ethical committee and the informed consent of each patient obtained. The study group consisted of women with non-specific inflammatory cervical smears who were invited to attend a colposcopy clinic for further investigation. The age range of the group was 16-69 (mean 29-1) years.

A second group of women with normal cervical smears who were receiving surgical treatment in hospital for conditions not associated with abnormal cytology - for example, hysterectomy for menorrhagia-were studied in parallel with the main group. The age range of this group was 17-70 years (mean 36.9). Biopsy specimens from the transformation zone were obtained at the time of surgery. All patients had been referred to the gynaecology clinic by their general practitioners for various gynaecological symptoms not associated with cervical disease.

\section{INVESTIGATIONS}

At the colposcopy clinic a standard "charcoal" cervical swab was taken for microbiological culture and placed in Amies's transport medium. "Plain" cotton wool cervical swabs were taken for chlamydial and virological culture 
and placed in the appropriate transport medium. All of these specimens were taken directly to the appropriate hospital laboratories. Routine cultures were set up to detect Neisseria gonorrhoeae, Candida albicans, and aerobic and anaerobic bacteria. Trichomonas vaginalis was identified by a fixed stain method with acridine orange. The viral swab was inoculated on to specific cell lines-for example, HEp ${ }_{2}$ and vero-a cytopathic effect indicating a viral infection. The chlamydial swab was inoculated on to cyclohexamide treated McCoy cells. These cultures were then stained with polyclonal antichlamydial rabbit serum, which reacts with all trachomatis subtypes.

Colposcopy of the cervix was performed and any areas of atypia identified. Wherever possible two adjacent biopsy specimens were taken from the identified lesions by colposcopically directed tissue sampling. If no lesion was visible then two specimens were taken adjacently but at random from the transformation zone, including the squamocolumnar junction when possible. One specimen was fixed in formalin for routine histological
TABLE II-F indings in 106 patients with non-specific inflammatory cervical smears and 104 patients with negative cytology

\begin{tabular}{|c|c|c|c|c|}
\hline & Normal & Inflammatory & $\begin{array}{l}\text { Warty } \\
\text { (viral)* }\end{array}$ & $\begin{array}{l}\text { Cervical intraepithelial } \\
\text { neoplasia/atypia }\end{array}$ \\
\hline \multicolumn{5}{|c|}{ Patients with non-specific inflammatory cervical smears } \\
\hline $\begin{array}{l}\text { Histology } \\
\text { Colposcopy }\end{array}$ & $\begin{array}{l}36 \\
38\end{array}$ & $\begin{array}{r}43 \\
1\end{array}$ & $\stackrel{14}{9+}$ & $\begin{array}{l}13 \\
64\end{array}$ \\
\hline \multicolumn{5}{|c|}{ Patients with negative cytology } \\
\hline Histology $\ddagger$ & 57 & 25 & 0 & 0 \\
\hline
\end{tabular}

*Criteria for these changes based on well recognised features (summarised in ref 28 ). †Six of these patients included in cervical intraepithelial neoplasia/atypia group. $\ddagger$ Histological study not performed in 22 patients of group.

TABLE I-Microbiological findings in 106 patients with non-specific inflammatory cervical smears

\begin{tabular}{lcccccc}
\hline & Bacteria & $\begin{array}{c}\text { Trichomonas } \\
\text { vaginalis }\end{array}$ & $\begin{array}{c}\text { Candida } \\
\text { albicans }\end{array}$ & $\begin{array}{c}\text { Herpes simplex } \\
\text { virus }\end{array}$ & Cytomegalovirus & $\begin{array}{c}\text { Chlamydia } \\
\text { trachomatis }\end{array}$ \\
\hline No of positive isolations & $6^{\star}$ & 0 & 2 & 0 & 1 & 2 \\
\hline
\end{tabular}

${ }^{\star}$ Five of these isolations were $\beta$ haemolytic streptococcus, which was considered to be a normal vaginal commensal.

examination and the other snap frozen in liquid nitrogen for future DNA hybridisation.

In the second group random biopsy specimens for DNA hybridisation were taken from the transformation zone at the time of surgery. The remainder of the specimen was fixed in formalin for routine histological examination

Molecularly cloned human papillomavirus DNA-Plasmids containing cloned DNA of human papillomavirus types $1,{ }^{11} 2,{ }^{12} 4,{ }^{11} 6,{ }^{13} 10,{ }^{14} 11,,^{15} 16,{ }^{8}$ and $18^{9}$ were propagated in Escherichia coli and their DNA prepared by established methods. ${ }^{16}$

Preparation of cellular DNA, restriction endonuclease digestion, gel electrophoresis, and blotting-The frozen tissue samples were cut into small pieces and disrupted in a microdismembranator (F-T Scientific Instruments, Gloucester). ${ }^{17}$ Cell nuclei were prepared by the method of Favaloro et al ${ }^{18}$ and the nucleic acids extracted from the nuclear pellet as described. The DNA was precipitated with ethanol, washed with $70 \%$ ethanol, dried, and resuspended in $10 \mathrm{mM}$ trometamol (TRIS) and hydrochloric acid $\mathrm{pH} 7 \cdot 9$ and $1 \mathrm{mM}$ edetic acid. The DNA concentration was measured by the mithramycin assay. ${ }^{19}$ Samples of cellular DNA $(10 \mu \mathrm{g})$ were digested with restriction endonuclease $P$ st $\mathrm{I}$ or $\mathrm{Bam} \mathrm{HI}$ and fractionated on $0.7 \%$ agarose gels, as described.$^{20}$ Samples of DNA from a known human papillomavirus negative normal cervix and a human papillomavirus positive cervical carcinoma or condyloma acuminatum were included on each gel as negative and positive controls. Pst I or Bam HI cleaved, molecularly cloned DNA of human papillomavirus types $6,11,16$, and 18 served as markers. After electrophoresis the gels were washed twice for five minutes in $0.25 \mathrm{M}$ hydrochloric acid ${ }^{21}$ and the DNA transferred to nitrocellulose ${ }^{22}$ (Schleicher and Schuell) or Hybond (Amersham) membranes. The membranes were then baked at $80^{\circ} \mathrm{C}$ in a vacuum oven.

DNA-DNA hybridisation-A mixed probe containing cloned DNA from human papillomavirus types $1,2,4,6,10,11,16$, and 18 was labelled with phosphorus- 32 by nick translation ${ }^{23}$ and hybridised to the filters as described by Johnson et al. ${ }^{24}$ The filters were finally washed twice for 30 minutes in $0.6 \mathrm{SSC}$ ( $1 \mathrm{SSC}$ is $0.15 \mathrm{M}$ sodium chloride, $0.015 \mathrm{M}$ trisodium citrate) and $0 \cdot 1 \%$ sodium dodecyl sulphate at $41^{\circ} \mathrm{C}$ (low stringency, $\mathrm{Tm}-40^{\circ}$ ) or $0.6 \mathrm{SSC}$ and $0 \cdot 1 \%$ sodium dodecyl sulphate at $60^{\circ} \mathrm{C}$ (high stringency, $\mathrm{Tm}-20^{\circ}$ ), as described. ${ }^{25}$ They were then dried and autoradiographed for one to seven days using preflashed Fuji $\mathrm{RX} x$ ray film. The autoradiographs were developed using an Agfa-Gevamatic 60 processor.

\section{Results}

Microbiology - Cultures for pathogenic bacteria, viruses, and chlamydia resulted in only a few positive isolations (table I).

Histology and colposcopy-Table II summarises the colposcopic findings in the group with non-specific inflammatory cervical smears and the histological findings for both groups of patients. Though many cervices appeared to show colposcopic atypia, cervical intraepithelial neoplasia was not found histologically in all cases, but many of these atypical areas contained inflammatory changes. This may be explained by the fact that the cervices were examined extremely critically colposcopically for the slightest evidence, of any acetowhite area. Acetowhite areas which are considered to be normalN such as immature squamous metaplasia, regenerating squamous epithelium, and the "congenital transformation zone" would therefore have been? included in the classification. The group of patients with negative cervicaL cytology showed no evidence of cervical intraepithelial neoplasia or viral $\mathrm{G}$ infection, but 25 of the 104 patients showed inflammatory changes.

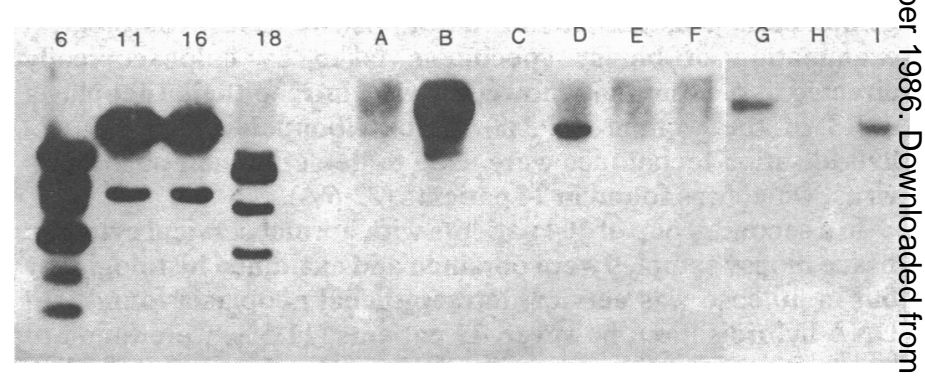

Low stringency blot hybridisation $\left(\mathrm{Tm}-40^{\circ}\right)$ of DNA from cervical biopsy? specimens using ${ }^{32} \mathrm{P}$ labelled mixed human papillomavirus DNA probe. DNAO samples digested with restriction enzyme $B a m \mathrm{HI}$ and products fractionated on$0.7 \%$ agarose gel. Lanes $6,11,16$, and 18 are marker tracks of respective molecularly cloned human papillomavirus DNA cleaved from plasmid vector with appropriate restriction enzyme. DNA obtained from normal cervix (lane A), squamous cervical cancers (lanes $B$ and $G$ ), and patients with non-specific inflammatory cervical smears (lanes C, D, E, F, H, and I). Specific single probeDNA hybridisation followed by high stringency wash $\left(\mathrm{Tm}-20^{\circ}\right)$ used too determine that human papillomavirus DNA in lanes D and I was type 16. Lanes C, D, and I showed following changes respectively: cervical intraepithelialo neoplasia stage III, cervical intraepithelial neoplasia stage II, and koilocytosis; remainder showed inflammatory changes. Human papillomavirus type 16 DNAN in squamous cell cancers (lanes B and G) appeared to be of larger molecular weight than viral unit length, suggesting that viral DNA was integrated into hosto cell DNA ${ }^{4243}$ In non-specific inflammatory cervical smears and normal samples human papillomavirus DNA appeared to be unit length, presumably episomalN forms.

DNA-DNA hybridisation-The figure shows examples of Southern blote hybridisation analyses. Table III shows that human papillomavirus type $16^{-}$ was the most frequently found in both groups of women. Human papillomavirus DNA was found in 24 of the 106 patients with non-specific $\frac{\text { P }}{\mathbb{P}}$ inflammatory cervical smears, roughly half of them coming from the category histologically positive for cervical intraepithelial neoplasia or virus. $\stackrel{1}{\Omega}$ The remainder showed a mainly inflammatory or, less often, normalo histological picture, which was usually associated with a "columnar ectopy." Of the 104 patients with negative cytology, 12 were positive for humano papillomavirus DNA. Half of these came from the group with histological 
TABLE III $\longrightarrow$ Summary of prevalence of human papillomavirus DNA

\begin{tabular}{|c|c|c|c|c|c|c|c|c|c|}
\hline & \multirow{2}{*}{$\begin{array}{l}\text { Total } \\
\text { No }\end{array}$} & \multicolumn{5}{|c|}{ Human papillomavirus } & \multicolumn{2}{|c|}{ Positive } & \multirow[b]{2}{*}{ Negative } \\
\hline & & Total & 6 & 11 & 16 & 18 & Mixed & Others ${ }^{\star}$ & \\
\hline $\begin{array}{l}\text { Non-specific inflammatory } \\
\text { cervical smears }\end{array}$ & 106 & 24 & - & 2 & 16 & - & 1 & 7 & 82 \\
\hline $\begin{array}{l}\text { Non-specific inflammatory } \\
\text { cervical smears with ectopy }\end{array}$ & 28 & 7 & - & - & 5 & - & - & 2 & 21 \\
\hline $\begin{array}{l}\text { Non-specific inflammatory } \\
\text { cervical smears positive } \\
\text { histologically for cervical } \\
\text { intraepithelial neoplasia or } \\
\text { virus }\end{array}$ & 27 & 12 & - & 2 & 8 & - & 1 & 3 & 15 \\
\hline $\begin{array}{l}\text { Non-specific inflammatory } \\
\text { cervical smears appearing } \\
\text { abnormal colposcopically }\end{array}$ & & & - & 2 & 10 & _ & 1 & 5 & 54 \\
\hline $\begin{array}{l}\text { abnormal colposcopically } \\
\text { Normal smears }\end{array}$ & $\begin{array}{r}70 \\
104\end{array}$ & $\begin{array}{l}16 \\
12\end{array}$ & - & $\underline{2}$ & $\begin{array}{r}10 \\
9\end{array}$ & - & - & 3 & $\begin{array}{l}34 \\
92\end{array}$ \\
\hline Normal smears with ectopy & 19 & 7 & - & - & 5 & - & - & 2 & 12 \\
\hline
\end{tabular}

*Samples positive for human papillomavirus DNA at low stringency using mixed probe but negative at high stringency with specific probes listed.

evidence of inflammatory changes. Seven of the 12 patients positive for human papillomavirus DNA were found to have columnar ectopy ("cervical erosion"), and overall 14 of all 49 cervical erosions in the two groups were positive for human papillomavirus DNA.

\section{Discussion}

These results show that there was a $12 \cdot 3 \%$ false negative rate for non-specific inflammatory cervical smears which were subsequently found to be cervical intraepithelial neoplasia and that a further $13 \cdot 2 \%$ of these patients showed histological evidence of infection with human papillomavirus. ${ }^{10}$ This false negative rate may have been due to several causes, which have been reviewed. ${ }^{26}$ Probably the most important factor in this study was suboptimal cytology. On colposcopic examination many of the areas of cervical intraepithelial neoplasia were noted to be very small and may well have been missed by even an experienced sampler. No evidence of cervical intraepithelial neoplasia or viral changes was found in the samples that were histologically normal.

Microbiological culture of pathogens from these patients yielded positive results in only a few. Hence it seems unlikely that these organisms play any part in the aetiology of non-specific inflammatory cervical smears. Nevertheless, neither bacteria, ${ }^{27}$ candida, ${ }^{27}$ trichomonas, ${ }^{28}$ nor chlamydia ${ }^{26}$ are regarded as strong contenders for aetiological agents in cervical cancer. There remained a proportion of patients, however, in whom inflammatory changes were detected histologically but in whom no causative agent could be found on the basis of available techniques.

Cytomegalovirus and herpes simplex virus were found in very few samples. In the case of herpes simplex virus this was probably due to latency of the virus. Positive cultures can be obtained only during active infection. Our figures agree with previous data for cytomegalovirus $^{29}$ and herpes simplex virus. ${ }^{27}$ Work is in progress to screen for herpes simplex virus DNA in the cervical samples by rehybridising the DNA on the filters to DNA fragments of herpes simplex virus type 2 .

The incidence of chlamydial infection was lower than expected but is known to range from $28 \%$ in women attending sexually transmitted disease clinics ${ }^{30}$ (S J Richmond, personal communication) to $11 \%$ for a control population, ${ }^{29} 7 \%$ for pregnant women routinely screened in an antenatal clinic, ${ }^{30}$ and $2.5 \%$ for all gynaecological outpatients (S J Richmond, personal communication).

From previous data DNA of human papillomavirus type 16 appears to be a risk factor for cervical cancer. ${ }^{35-9}$ In this study cervical biopsy specimens from 16 of 106 patients with non-specific inflammatory cervical smears were positive for human papillomavirus type 16 DNA. This correlates with the results of Prakash et al, who found that $12 \%$ of patients with histologically confirmed cervicitis were positive for human papillomavirus type 16 DNA. Half of the lesions of cervical intraepithelial neoplasia were positive for human papillomavirus DNA, which agrees with the findings of others. ${ }^{57}$ Nevertheless, a much higher proportion might have been expected..$^{31}{ }^{32}$ This discrepancy may be explained by the small size of the lesions, which made it difficult to obtain representative samples for both histological and hybridisation examinations.

In contrast with other studies ${ }^{37}$ human papillomavirus DNA types 6 and 11 were found rarely or not at all (table III). Human papillomavirus type 18 , though found in other countries, ${ }^{90}$ was not identified in any sample. These findings agree with those of D J McCance (personal communication); human papillomavirus type 18 has, however, recently been identified in Scotland (M S Campo, personal communication).

An interesting finding was that 14 of all 49 cervices with columnar ectopy $(29 \%)$ were positive for human papillomavirus DNA.1033 Just over half of these patients had normal cervical smears. Possibly human papillomavirus is harboured in cervical "erosions" close to the squamocolumnar junction after venereal transmission in sexually active women at risk..$^{34}$ This site is actively involved in the transformation zone which undergoes squamous metaplasia, which may facilitate entry of human papillomavirus into the cell and then initiate the process of cervical intraepithelial neoplasia, possibly being triggered by some other agent. ${ }^{35}$ This evidence concurs with epidemiological evidence that adolescent coitus ${ }^{36}$ and childbearing ${ }^{37}$ increase the risk of cervical cancer. It is at these times that an erosion is likely to be present because of an excess oestrogen effect, ${ }^{38}$ so presenting a suitable initial habitat for human papillomavirus. This hypothesis may incriminate the combined oral contraceptive pill as a risk factor because it has an excess oestrogen effect which promotes the development of columnar ectopy. ${ }^{339}$ This supports the findings of Vessey et al, who found that long term use of the pill increased the risk of cervical neoplasia when compared with the intrauterine device as a method of contraception. ${ }^{40}$ Our own figures (not given) showed that ectopic states were more common in those who had taken the pill recently. All of the human papillomavirus DNA positive patients with ectopy and most of the patients with non-specific inflammatory cervical smears who were positive for human papillomavirus DNA had also taken the pill recently. By comparison, most of the patients with non-specific inflammatory cervical smears who had no evidence of any abnormality had never taken or not taken the pill for some time. There appeared to be no relation of any of these abnormalities to age or parity in our series.

In this study a high proportion of human papillomavirus type 16 DNA was found. It seems likely that certain patients with columnar ectopy and non-specific inflammatory cervical smears are "at risk" groups because they have a greater chance of harbouring human papillomavirus DNA. The latter group contained an appreciable proportion found to have cervical intraepithelial neoplasia. We recommend that this group should have colposcopy, which will help to identify those whose cervices contain human papillomavirus sequences. These patients will then require close follow up or treatment, or both, as indicated by the colposcopic findings. Furthermore, it appears prudent to treat cervical ectopic states by locally destructive methods in women at risk in order to break this possible chain of infection. These methods have been found by Vonka et al to protect against the development of cervical neoplasia. ${ }^{41}$

We conclude that patients with non-specific inflammatory cervical smears should be paid as much attention as those whose cervical smears show cervical intraepithelial neoplasia. They should have frequent, regular, repeated cervical smears as a bare minimum and ideally a colposcopic examination and should not merely be ignored and said to be normal because the cytology report does not show a severe abnormality.

This work was supported by grants from the North Western Regional Health Authority and the Cancer Research Campaign. Bacteriological and histological studies were kindly performed by the departments of bacteriology and pathology at North Manchester General Hospital. We are grateful to the North Manchester Regional Virus Laboratory for undertaking the chlamydial and virological cultures. We thank Dr S Burnette for cloned DNA from human papillomavirus types 1, 2, 4, and 10 and Professor $\mathrm{H}$ Zur Hausen for clones of human papillomavirus types $6,11,16$, and 18 DNA. 


\section{References}

1 Meisels A, Fortin R, Roy M. Condylomatous lesions of the cervix. II. Cytologic, colposcopic and histopathologic study. Acta Cytol 1977;21:379-90.

2 Reid R, Stanhope CR, Herschman BR, Booth E, Gibbs GD, Smith JP. Genital warts and cervical cancer. I. Evidence of an association between subclinical papillomavirus infection and cervical malignancy. Cancer 1982;50:377-87.

3 McCance DJ, Walker PG, Dyson JL, Coleman DV, Singer A. Presence of human papillomavirus DNA sequences in cervical intra-epithelial neoplasia. Br.Med f 1983;287:784-8.

4 Gissman L, Wolnik L, Ikenberg H, Koldovsky U, Schnarch HG, Zur Hausen H. Human papillomavirus types 6 and 11 DNA sequences in genital and laryngeal papillomas and in some cervical cancers. Proc Natl Acad Sci USA 1983;80:560-3.

5 Prakash SS, Reeves WC, Sisson GR, et al. Herpes simplex virus type 2 and human papillomavirus type 16 in cervicitis, dysplasia and invasive cervical carcinoma. Int $f$ Cancer 1985;35:51-7.

6 Scholl SM, Kingsley-Pilliers EM, Robinson RE, Farrell PJ. Prevalence of human papillomavirus type 16 DNA in cervical carcinoma samples in East Anglia. Int $\mathcal{f}$ Cancer 1985;35:215-8.

7 Crum CP, Ikenberg H, Richart RM, Gissman L. Human papillomavirus type 16 and early cervical neoplasia. N Engl f Med 1984;310:880-3.

8 Durst M, Gissman L, Ikenberg H, Zur Hausen H. A papillomavirus DNA from a cervical carcinoma and its prevalence in cancer biopsy samples from different geographic regions. Proc Natl Acad Sci USA 1983;80:3812-5.

9 Boshart M, Gissman L, Ikenberg H, Kleinheinz A, Scheurlen W, Zur Hausen H. A new type of papillomavirus DNA, its presence in genital cancier biopsies and in cell lines derived from papillomavirus DNA, its prevence in genital
cervical cancer. F:MBO Joumal 1984;3:1151-7.

$10 \mathrm{Koss}$ LG. Diagnostic cylology and its histopathologic bases. 3rd ed. Vols I, II. Philadelphia, Toronto: J B Lipincott, 1979.

1 Gissman L, Pfister H, Zur Hausen H. Human papillomaviruses: characterisation of four different isolates. Virology 1977;76:569-80.

12 Orth G, Favre $M$, Croissant $O$. Characterisation of a new type of human papillomavirus that causes skin warts. $\mathcal{F}$ Virol 1977;24: 108-20

13 Gissman L, Zur Hausen H. Partial characterisation of viral DNA from human genital warts (condylomata accuminata). Int $\mathcal{f}$ Cancer 1980;25:605-9.

14 Green M, Brackmann KH, Saunders PR, et al. Isolation of a human papillomavirus from a patient with epidermodysplasia verruciformis: presence of related viral DNA genomes in human urogenital tumors. Proc Natl Acad Sci USA 1982;79:4437-41.

15 Gissman L, Diehl V, Schultz-Coulon HJ, Zur Hausen H. Molecular cloning and characterisation of human papillomavirus DNA derived from a laryngeal papilloma. $\mathcal{F}$ Virol 1982;44:393-400.

16 Maniatis T, Fritsch EF, Sambrook J. Molecular cloning. A laboratory manual. New York: Cold Spring Harbor Laboratory, 1982:150-63.

17 Kreig P, Amtmann E, Sauer G. The simultaneous extraction of high molecular weight DNA and of RNA from solid tumors. Anal Biochem 1983;134:288-94.

18 Favaloro J, Treisman R, Kamen R. Transcription maps of polyoma virus-specific RNA: analysis by 2D nuclear mapping. Methods Enzymol 1980;65:718-49.

19 Hill B'T, Whatley S. A simple, rapid microassay for DNA. FEBS Lett 1975;56:20-3

20 Arrand JR, Keller W', Roberts RJ. Extent of terminal repetition in adenovirus-2 DNA. Cold Spring Harbor Symp Quant Biol 1974;39:401-7.

21 Wahl GM, Stern M, Stark GR. Efficient transfer of large DNA fragments from agarose gels to diazobenzyloxymethyl paper and rapid hybridisation using dextran sulphate. Proc Natl Acad Sci USA 1979;76:3683-7.
22 Southern EM. Detection of specific sequences among DNA fragments separated by electrophoresis. F Mol Biol 1975;98:503-17.

23 Rigby PWS, Dieckman $M$, Rhodes C, Berg P. Labelling deoxyribonucleic acids to high spec activity in vitro by nick translation with DNA polymerasel. 7 i

24 Johnson DA, Gautsch JW, Sportsman JR, Elder JH. Improved technique utilising non-fat of milk for analysis of proteins and nucleic acids transferred to nitrocellulose. Gene Analy Techniques 1984:1:3-8.

25 Howley PM, Israel MA, Law MF, Martin MA. A rapid method for detecting and mappi homology between heterologous DNAs. Evaluation of polyomavirus genomes. $7 \mathrm{Biol}$ Ch 1979;254:4876-83

26 Jordan JA, Sharp F, Singer A, eds. Pre-clinical neoplasia of the cervix: proceedings of ninth study group of the Royal College of Obstetricians and Gynaecologists, October 1981. London: RoG College of Obstetricians and Gynaecologists, 1982.

27 Alexander ER. Possible etiologies of cancer of the cervix other than herpes virus. Cancer $\dot{R} \dot{e}$ 1973;33:1485-90.

28 Bertini B, Hornstein M. The epidemiology of trichomoniasis and the role of this infection in th development of carcinoma of the cervix. Acta Cytol 1970;14:325-32. 29 Gutman LT, Wiesner PJ, Holmes KK, Wentworth BB, Alexander ER. Microbiologic correla
of cervicitis. Clinical Research 1972;20:529.

30 Woods PL, Hobson D, Rees E. Genital infections with chlamydia trachomatis in women attendif

an antenatal clinic. Brf Obstet Gynaecol 1984;91:1171-6.
31 Crum CP, Mitao M, Levine RU, Silverstein S. Cervical papillomaviruses segregate with morphologically distinct precancerous lesions. $\mathcal{F}$ Virol 1985;54:675-81.

32 Gissman L. Presence of human papillomavirus in genital tumors. F Invest Dermatol 1984;83 1 (suppl):26-8s.

33 Haines M, Taylor CW. Gynaecological pathology. London: J and A Churchill Ltd, 1962.

4 Campion MJ, Singer A, Clarkson PK, McCance DJ. Increased risk of cervical neoplasia consorts of men with penile condylomata acuminata. Lancet 1985;i:943-6.

35 Zur Hausen H. Human genital cancer: synergism between two virus infections or synergis between a virus infection and initiating events? Lancet 1982;ii:1370-2.

36 Rotkin ID. A comparison review of key epidemiological studies in cervical cancer related current searches for transmissible agents. Cancer Res 1973;33:1353-67.

37 Christopherson WM, Parker JE. Relation of cervical cancer to early marriage and childbearing. Engl f Med 1965;27:235-9. 38 Hellman LM, Rosenthal AH, Kistner RW, Gordon R. Some factors influencing the proliferatiof
of the reserve cells in the human cervix. Am f Obstet Gynecol 1954;67:899-915.

39 Clayton SG, Fraser D, Lewis TLT. Gynaecology by ten teachers. 12th ed. London: Edward Arnold 1971:170-81.

40 Vessey MP, Lawless M, McPherson K, Yates D. Neoplasia of the cervix uteri and contraception. possible adverse effect of the pill. Lancet 1983;ii:930-4

41 Vonka V, Kanka J, Jelinek J, et al. Prospective study on the relationship between cervi이 intraepithelial neoplasia and herpes simplex virus type 2. I. Epidemiological characteristics. HSV-2 antibody presence in sera taken at enrolment. Int $\mathcal{F}$ Cancer 1984;33:49-66.

42 Durst M, Kleinheinz A, Hotz M, Gissman L. The physical state of human papillomavirus type If DNA in benign and malignant genital tumours. F Gen Virol 1985;66:1515-22.

43 Lehn H, Kreig P, Sauer G. Papillomavirus genomes in human cervical tumors: analysis transcriptional activity. Proc Natl Acad Sci USA 1985;82:5540-4.

(Accepted 1 September 1986

\section{YEARS AGO}

The continental tourist is apt to be somewhat embarrassed by questions of dietary, and more especially by not unfounded suspicions regarding his water-supply. In Switzerland, the water is for the most part above reproach; but it is otherwise in many other parts of the Continent. The Englishman is almost morbidly sensitive on this point; and, when his fears are once excited, he shuns his natural beverage with perhaps undue alarm, and takes refuge in unlimited indulgence in wines and mineral waters. Here, as often, we shun Scylla to fall into Charybdis. It is well to avoid the typhoid germs possibly lurking in the water-bottle; but, to court dyspepsia by an unaccustomed indulgence in acid wines, or waters largely impregnated with mineral matter, is not well. A little claret or hock can do no harm, and, where the ordinary water-supply lies under any just suspicion, the tourist may with advantage use Apollinaris, St. Galmier, or other natural water, in which the proportion of saline material is small. The waters which contain a large percentage of carbonates, chlorides, or sulphates, are quite unsuitable for common use, especially with food. (British Medical fournal 1886;ii:465.)

Near the bottom of the Broad Walk in Kensington Gardens, and about a hundred yards below the Round Pond, is situated a sunken well bearing the inscription "St. Govor's Well, 1856." A few years ago, the water, which issued in a considerable stream from a leaden spout, was credited with medicinal virtues, and was distributed to children and curious people in many coloured glasses by an old woman who attended daily. We have heard of the beneficial action of the waters on crippled joints. Since the woman disappeared (from over-indulgence in the waters?) a metal cup has been attached to the spout, and the well has been the constant resort of thirsty children and nursery-maids. During the past summer, while the Round Pond has been drained St. Govor's Well has run dry, and it is said that some pipes were discovered under the two or three feet of stinking mud at the bottom of the pond which had the appearance of communicating directly with the well, so that it seems probable that the water has been filtered through the mud, and not through the intervening bed of gravel. Can its reputed medicinal virtues be due to the organic impurities of stagnant water It is to be hoped that the source of the water will be fully investigated, and, it is found to be the mere drainage of the pond, that the well will be closed,

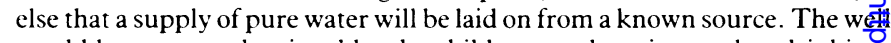
would be very much missed by the children, as there is no other drinkingfountain in the gardens. (British Medical fournal 1886;ii:936.)

A correspondent writes: The extended consumption of one or the other this class of substances points to the existence of some beneficial effect to derived therefrom, although what this consisted in it has been difficult ${ }_{0}$ say, judging otherwise than subjectively. Sir William Roberts, of Mañ chester, has lately suggested an ingenious hypothesis, which offers ${ }_{3}$ plausible explanation of their use. Man, in a state of nature, would derive his sustenance presumably from materials which, from their being raw, or any rate imperfectly cooked, would be necessarily but slowly digested a assimilated. With civilised communities, on the contrary, everything is do with the view of faciliating digestion, by the removal of indigestible parts $f f$ the food, or by submitting them to processes which favour the action of the juices with which they are to be brought into contact. Under these circumstances, it is quite possible that digestion and assimilation may proceed at a speed not only unnecessary, but even disturbing, to equilibrium of the organism, and provocative of waste. The employment $8 \mathrm{f}$ alcohol, tea, coffee, etc., would tend to correct this undesirable acceleration of the assimilative processes; for Sir W. Roberts has proved, by a series carefully conducted experiments, that their effect is powerfully to retard the action of the various digestive ferments on the foods; and it may be that the instinctive sense of the benefit thereby derived lies at the root of the yearnis of all civilised nations for such substances. Again, some condiment, such common salt, is added, to restore sapidity to articles from which the salts have been removed in the process of cooking; and, taken in excess, it ond throws extra work on the organs of excretion. (British Medical fourkal 1886;i:126.) 